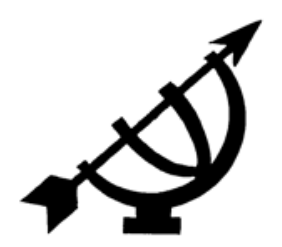

\title{
The necessity of an integral Christian worldview: reconnoitring the challenges for influencing the unbelieving world
}

\author{
P.M. Theron \& G.A. Lotter \\ School of Ecclesiastical Sciences \\ Faculty of Theology \\ Potchefstroom Campus \\ North-West University \\ POTCHEFSTROOM \\ E-mail: ptvila@gmail.com \\ george.lotter@nwu.ac.za
}

\begin{abstract}
The necessity of an integral Christian worldview: reconnoitring the challenges for influencing the unbelieving world

Christians often conclude from the apostle Paul's warning: "Do not be yoked together with unbelievers" (2 Cor. 6:14), that he condemns all contact with non-Christians and advocates total withdrawal from the world. However, Christians are called to "influence the world". They need to find the fine balance between an exclusive and an accommodating Christianity. Being continously aware of and grounded in the Christian worldview will guide Christians to realise their calling to be "reformers" in all spheres of life. Christians are called to contribute to society's transformation by means of a comprehensive view of full-time service to God in every area of life. Christianity can only influence the world effectively if it is grounded in an integral Christian worldview and continually addresses the economy, politics, society, culture, religion, education and society as a whole. Flowing from the discussion, proposed guidelines for influencing the unbelieving world will be given at the end of the article.
\end{abstract}




\section{Opsomming}

\section{Die noodsaaklikheid van 'n integrale Christelike wêreldbeskouing: verkenning van die uitdagings vir beïnvloeding van die ongelowige wêreld}

Christene dink dikwels dat die apostel Paulus met sy waarskuwing: "Moenie met ongelowiges in dieselfde juk trek nie" (2 Kor. 6:14), alle kontak met nie-Christene veroordeel en dat hy totale onttrekking aan die wêreld voorstaan. Christene word egter geroep om die "wêreld te beïnvloed". Hulle moet die fyn balans tussen 'n eksklusiewe en 'n akkommoderende Christenskap vind. ' $n$ Voortdurende bewuswees van en gegrondwees in die Christelike lewensbeskouing, sal Christene laat besef dat hulle 'n roeping het om "hervormers" op alle terreine van die lewe te wees. Christene is geroep tot transformasie van die gemeenskap deur middel van 'n omvattende beeld van voltydse diens aan God op elke terrein van die lewe. Die Christendom kan alleen die wêreld effektief beïnvloed indien dit in 'n integrale Christelike wêreldbeskouing gegrond is en voortdurend betrokke is by die eise van die ekonomie, politiek, gemeenskap, kultuur, godsdiens, opvoedkunde en die gemeenskap in sy totaliteit. Voortspruitende uit die artikel, word ten slotte riglyne voorgestel vir die beïnvloeding van die ongelowige wêreld.

\section{Introduction and problem statement}

From passages in Scripture, for example "Do not be yoked together with unbelievers" (2 Cor. 6:14), Christians might conclude that Paul condemns all contact with non-Christians and advocates withdrawal from the world. The converse, however, is true, namely that Christians are called to influence the world (Matt. 5:13-16; 28:19-20). To find the equilibrium between being exclusive and accommodating is one of the major difficulties for Christians in the 21st century.

The objective of this article is to investigate why an integral Christian worldview is imperative and how believers can positively influence the unbelieving world around them by their worldview and through their everyday living.

This approach and focus may seem to be one-sided Christian and only reflecting the reformed worldview, but fits into the expressed parameters of Koers to have "... an integrated worldview as foundation ..." and "... be embedded within a wider (philosophical) framework" (Anon, 2008:372). Although the reformed worldview is defended in this article, it is not condescending towards other worldviews. The article tries to revisit and reiterate the challenges for 
influencing the unbelieving world from the side of an integral Christian wordview.

Although the focus of the article is on the individual Christian, the believer often finds him-/herself within a community of believers, the church. Barna (2006:x) defines the church as the congregationbased faith experience, which involves a formal structure, a hierarchy of leadership and a specific group of believers. In this article, when reference is made of the church, the collective voice of a community of believers is implied. It is clear that the church has a responsibility to give guidance to individual members on how to positively impact the world. A study will be made of the importance of a Christian worldview and a Christian value system to give contemporary Christians possible guidelines on how to act in situations where they are "unequally yoked". The role Christians should play with regard to inter alia the society at large, politics, economy and business, education, science, media and justice will be investigated. To conclude, some guidelines will be proposed on how the Christian integral worldview may be applied living in an "unequally yoked context" and influencing the unbelieving world.

In Scripture one is reminded of the words of Paul: "Do not be yoked together with unbelievers" (2 Cor. 6:14) which clearly addresses the relationship between unbelievers and believers (Theron, 2004:42). New Testament commentators like Barnett (1999:130) and Garland (1999:331) agree that Paul wants to teach believers that they cannot live the same kind of life than unbelievers. Theron (2004:41-43) explains how Paul metaphorically applies the Old Testament prohibition of yoking different animals together (Deut. 22:10; Lev. 19:19) to warn believers not to become intimately involved with unbelievers (2 Cor. 6:14-16). This commandment accentuates the necessity of holiness and thus forbids Jews to plough with an ox (clean) and a donkey (unclean) yoked together (VanGemeren, 1997:296). Although the principles presented in this passage are applicable to contemporary believers, they should not conclude that Paul condemns all contact with non-Christians and advocates total withdrawal for fear of contamination (1 Cor. 5:9-11). The metaphor of the "unequal yoke" refers to close relationships where Christian beliefs can be compromised unless both parties are true believers. Christians are urged to break with any form of unhealthy compromise so that the church and individual believers can live according to God's desires (McDougall, 1999:114, 121, 127-137).

Christians are imitators of Jesus Christ and should therefore follow his modelled lifestyle: to be in the world, but not of it (John 17:14- 
15). Van der Walt (1994:448) urges believers to find the balance between withdrawal (isolation) on the one hand and being swallowed up by the world (accommodation) on the other.

The question remains as Theron and Lotter (2008:284) posed it:

How should Christians, living in today's context, have a positive influence on the world around them? It will not happen if they are accommodative towards a society which ignores God's norms. Neither will it happen if they isolate themselves from the 'sinful' world. (Cf. also Van der Walt, 2007:2, 4.)

Hauerwas and Willimon (1989:30) observe that since Constantine, the church was judged politically by how its presence in the world is advantageous for the world. Believers should, through consistent devotion to Biblical principles, influence the world instead of being influenced by it (Barna, 2006:70-71). Being aware of others' worldviews will enable Christians to effectively share Christ's message (Arch, 2007).

\section{A Christian worldview for contemporary Christians}

It is essential to explore the Christian worldview as it emphasises a Christian's way of seeing, understanding, interpreting, approaching and applying the totality of human life from the perspective of Christian history and Biblical principles (Anon., 2007a). It explains what Christianity and the Bible teach about human endeavours in life and assists believers to relate Christian faith to real life situations (Turaki, 1999:21-22). In order to better understand and explicate what a worldview (and more specific a Christian worldview) is, the following aspects regarding worldview will be discussed: definition, the role of religion, the history of the Christian worldview and the influence a Christian worldview may have on contemporary Christians.

\subsection{Definition of a worldview}

Every person has a worldview, even if he/she is not able to articulate it clearly, because it is part of being an adult human being (Wolters, 2005:4). Various disciplines define the term worldview as the distinctive view that people have of reality, including the "unproven" and "unquestioned assumptions" about reality (Howell, 2006:310). Words closely related to worldview is belief-systems and life perspectives. It serves as a guide to life, a compass to orient people in the world and presents a perspective on the origin, value, meaning and destination of the human race and the world. It provides a comprehensive understanding of God, the world, and man's relationship 
with God and the world (Noebel, 1991:8; Bosman, 2002:87-89; Schoeman, 2004:173, 182; Wolters, 2005:2, 5).

A worldview addresses the following seven basic questions (Sire, 1997:17-18):

- What is the ultimate reality? (Nature and character of God.)

- What is the nature of external reality? (Nature of the universe.)

- What is a human being? (Nature of humanity.)

- What happens to a person at death?

- Why is it possible to know anything? (Basis of human knowledge.)

- How do we know what is right and wrong? (Basis of ethics.)

- What is the meaning of human history?

\subsection{The role of religion in a worldview}

The word secular implies the absence of a religious foundation, but the "absence of a religious foundation" is in itself a religious belief, namely that there is no God. A worldview can never be free from some kind of religious perspective (Anderson et al., 2000:38; Hulst, 2004:11). Furthermore, the worldview of a person will determine whether he/she will be religiously involved in the world (Larney \& Lotter, 2006:10). Man's decisions and actions are determined by his/her principles, norms and values which in turn are determined by his/her worldview (Balasuriya, 2001:32; Lategan, 2003b:217). Religious convictions thus play an important role in the forming of a person's worldview (Schoeman, 2004:182; Shaw, 2005:10; Larney \& Lotter, 2006:8). For a worldview to be adequate, Sire (1997:196198) mentions the following requisites:

- It should be intellectually consistent and logic.

- It should be able to handle data about reality.

- It should explain what it claims to explain.

- It should satisfy people subjectively and that only happens if it is true.

There are numerous worldviews to choose from, but the Christian worldview is the only one which provides a consistent explanation of all facts of reality and satisfactory complies with all above-mentioned 
requirements (Noebel, 1991:13; Sire, 1997:18, 198). If the Christian worldview is not integral, effective and guiding the Christians in this world, the danger may arise that many people (including Christians) are so secularised that the Christian faith and the implications thereof are not relevant any more (White, 2001:170).

\subsection{The history of the Christian worldview}

The concept Christian worldview was first formulated by Augustine (AD 354-430), but its influence declined during the Middle Ages ( $\pm 400- \pm 1400)$ with the upcoming of dualism. During the sixteenth century, Luther, Zwingli and especially Calvin during the Reformation succeeded to break through the dualistic Christendom in which Christians divided life into a sacred sphere which is under the governance of God and a secular sphere under control of man. Calvin is an exceptional example of someone who "practiced what he preached" in the city of Geneva where he was intimately involved in the well-being of the city (Noordegraaf, 2009:268 ff.) during his stay there (1536-1538 and 1541-1564). He not only had a definite Christian worldview, he also lived it out! The Reformation emphasised sola Scriptura (the Word of God alone is the guiding principle for everyday life). Two other essential principles also came to the fore: sola gratia (grace alone) and sola fide (faith alone). After two centuries, Kuyper accentuated again the concept that the Reformation should encompass the politics, economy and education (Van der Walt, 1994:118-120, 305; Shorter \& Onyancha, 1997:13-14; Zwemstra, 2006:20). Wolters also describes the development of a Biblical worldview as a desire to live according to Scripture in all areas of life and work (Wolters, 2005:1; Hulst, 2004:8).

\subsection{The Christian worldview shaped by the Bible}

As a worldview refers to "the comprehensive framework of one's basic beliefs about things", it follows that the Christian will demand that his/her worldview should be shaped by and tested against the Bible. The reformational worldview relates to the three central themes of Scripture, namely creation, fall and redemption (Wolters, 2005:2, 7, 12). Question 2 of the Heidelberg Cathechism (one of the central creeds of the Reformation) also divides the substance of what believers should know, i.e. the contents of the Scripture, in three parts, namely the misery (fall), deliverance (redemption) and gratitude (Vorster, 2007:13-15). God is the sole and absolute Origin of the existing reality. The intimate fellowship which existed between God and man was disrupted because of the fall when humankind turned away from God in disobedience and spiritual death followed. 
The redemption through Jesus Christ redirects the fallen man to the true Origin and makes fellowship with God possible again. The regulating principle in the Christian's life is the commandment of love for God and fellow humans, but the ever present tribulations of sin causes a continual struggle which can only be overcome through the grace of God (Hulst, 2004:15; Schoeman, 2004:187-189).

The Christian worldview reflects the criteria as set by Sire (1997:2338):

- God is infinite and personal (triune), transcendent and immanent, omniscient, sovereign and good.

- God created the cosmos ex nihilo to operate with a uniformity of cause and effect in an open system.

- Human beings are created in the image of God, having personality, self-transcendence, intelligence, morality, gregariousness and creativity.

- Human beings were created good, but through the fall, the image of God became defaced. God redeemed humanity through Jesus Christ, but each person can choose to accept or reject Him. Death is either the gate to life or to eternal separation from God.

- Human beings can know the world around them and God himself, because $\mathrm{He}$ has given them the ability and $\mathrm{He}$ communicates with them.

- Ethics is transcendent and based on the character of God as good, holy and loving.

- History is linear and leading to the fulfilment of God's purposes for humanity.

\subsection{The influence of a Christian worldview on contemporary Christians}

The Christian worldview defines all relationships of the believer, because the primary relationship between the creature and his Creator encompasses all other relationships. Believers' lives thus become other-orientated, characterised by mercy, love and justice (Hollinger, 2004:41; Schoeman, 2004:194). Furthermore, the Christian worldview impacts the whole life of the believer - to obey and honour God in every aspect of life. It enables the believer to relate his/her faith to all spheres of life by motivating him/her to live out his/her calling to make the world a better place. It gives believers 
direction, new perspectives and solutions for everyday problems (Van der Walt, 1994:33, 54; Kok, 2004:99). Ecology can serve as an illustration of how the Christian worldview impacts life as a whole. In 1994, an evangelical declaration on the care of creation was formally issued and reaffirms that the earth belongs to God and that humankind is responsible to Him for it. It encourages Christians to maintain the Biblical mandate for creation care in the face of accusations that Christianity is incompetent to react positively to environmental issues (Berry, 2000:17). In her article on ecology, Primavesi $(2006: 437,440)$ mentions how there is a movement away from the traditional Christian stance that the Creator intended all the treasures of nature for the sake of man, to an acceptance of man's proper place in the environment and the realisation that man cannot, without severe consequences, assume the right to use earth's resources for his exclusive benefit. Passages in Scripture like Colossians 1:15-17 which state that all things were created by Him and for Him, help Christians to understand that their commitment to Jesus Christ also implies a commitment to God's earth (Echlin, 2004:7). Man's ecological responsibility finds its Biblical balance in dominion exercised through servanthood (Wright, 2004:126; French, 2005:470).

One of the most important influences of the Christian worldview is to compel believers to break loose from dualism which has paralysed Christianity and robbed it of its capacity to impact public affairs and transform the world (Voyé, 1999:275; Van der Walt, 2003:541; Heyns, 2006:1). A dualistic worldview caused the rapid secularisation of the Western world as Christians avoided the field of art, education, politics, healthcare, et cetera and left it to non-Christians. The Christian worldview is an integral worldview which helps believers to realise that the Bible has much to say about business, science, technology and other social issues and that they are called to serve God full-time in all areas of life (Wolters, 2005:8-9, 12; Anon., 2007a).

The believer's calling is not to move out of the world, but to move in the world, to read the Bible and the newspaper together - to be critically active in society (Smit, 2002:125, 135-136; Hulst, 2004:12) and this corresponds with the claim of Richard Niebuhr that Christ is the transformer of culture. A Christian worldview helps believers to realise that they are called to be "reformers" of society: everything which was formed in creation, was deformed by sin and needs to be reformed in Christ according to the guiding principles of the Reformation, namely sola Scriptura, sola gratia and sola fide (Wolters, 
2005:77-78; Zwemstra, 2006:21). The liberating influence of the Reformation can for instance be seen by inter alia the changing view regarding marriage (Lotter, 2004:26-27) and other features of society changed by the Reformation (cf. Hoek, 2009:179).

\section{The Christian worldview and the implications for morals and ethics for contemporary Christians}

The Christian worldview shows certain results in people's lives, for instance in moral and ethical values. Moral and ethical values can be defined as guidelines for responsible and acceptable decisions regarding oneself, one's place in society and the world. These values consequently determine one's behaviour and are applicable in all walks of life (Lategan, 2003a:363; Steyn, 2005:82; Lotter, 2007a:3). According to Niebuhr, the highest expression of Christian morality is self-sacrificial love as demonstrated by Jesus Christ on the cross (Browning, 2006:28).

The Christian worldview also has ramifications which will be discussed with regard to the influence of postmodernism, the need of ethics and a value system, the establishment of a Christian value system, and the impact of Christian ethics on the world.

\subsection{The influence of postmodernism}

Relatively few people today refer to the Bible as a guide in matters of morality (Tate, 2006:517). Postmodernism advocates that there is not only one truth, but different truths. The standards for distinguishing between right and wrong are no longer universal, but rooted in particular languages and cultures. People lost their set certainties and predetermined ethical values and it is replaced by pluralism and relativism. Moral judgement becomes difficult and values become privatised (Vanhoozer, 1998:9; Vergeer, 1999:14; Janse van Rensburg, 2000:69-70; Prins, 2001:106; Hulst, 2004:10; Steyn, 2005:51-53). Postmodernism focuses on the individual - how he/she sees reality is determined by his/her religion, culture and worldview. One person's reality may completely differ from another person's reality. This gives rise to common slogans like "Nothing is sacred" and "Everything goes" (Vorster, 1999:11). Man is the reference for truth and he/she is only responsible to him-/herself (Lategan, 2003a:362). The resultant liberalist idea that man is free of any norms may be the origin of the current morality crisis in South Africa (De Villiers, 2000:440; Phillip, 2007:1). 


\subsection{The need of ethics and a value system}

Happenings like the Enron scandal in 2001, crime and corruption show that society cannot function without ethics (Lategan, 2003a: 361). People from different cultural and religious backgrounds are searching for new norms. They are looking for values which can be applied in their changing world to guide them through their daily choices. They want to do what is right and not necessarily what is legitimate (Jordaan, 2000:30; Steyn, 2005:82). Focusing only on Africa, Turaki (1997:2) observes that many religious, cultural, political and economic models have been applied in an attempt to solve the problems of modern Africa, but the prognosis remains dismal. He argues that the continent's problems are deeper than a correct political or economic system and believes that only programs based on morality and ethics can effectively address Africa's problems. The South African society, remarks Heyns (2006:1), is characterised by inter alia AIDS, poverty, crime and racism. Referring to the example of Uganda where the AIDS pandemic was turned around with the help of a Christian ethos, he believes that Christianity can have a constructive effect on society. Lategan (2003a:362) observes that there is a growing resistance in South Africa against the "freewheeling society" as people demand the "healing" of society through ethics.

\subsection{The establishment of a Christian value system}

According to Alfeyev (2005:86), there are two main groups of value systems, namely the Christian value system and the "common human values" of secular humanism. The former is theocentric (the Word of God is the measure for truth - John 17:17) and the latter is anthropocentric (man is the yardstick of truth). It is obvious that Christians cannot accept the second option. Kohlberg's theory on moral development states that children younger than nine years learn about norms and values by the example of adults and by the consequences (reward/punishment) of their conduct - the preconventional phase. After nine years, follows the convention phase in which values are determined on the ground of identification with the group. Kohlberg believes that the majority of people stay in this phase and only a minority enter the post-conventional phase where moral decisions are based on self-defined moral values (Prins, 2001:109).

Although role-players like peer groups, media and schools have an influence in the forming of values, parents are the primary agents in the development of the child's moral values (Prins, 2001:108; Steyn, 
2005:82; Lotter 2007a:3). The success of the transmission of values from parents to children, according to Lotter (2007a:8-9), is determined by the cohesion, the flexibility and the communication of the family. Prins (2001:108-110) also stresses the importance that children should experience their parents' religion as credible and not mere lip-service, while Jordaan (2000:30) believes that new ethics should be acquired by doing. Children should be taught how to think, and not what to think. They should learn about sensitivity, honesty and responsibility. They should learn how to solve conflict without violence, how to live without fear and how to conquer selfishness. Prins (2001:115-116) adds that children should be taught decisionmaking skills, as they will encounter situations with no ready-made answers. Children must be assisted to move from the conventional to the post-conventional phase - "outside" values should become internalised convictions.

\subsection{The impact of Christian ethics on the world}

In South Africa, liberal democracy replaced the system of apartheid and after three peaceful general elections, the new dispensation can be considered a success, but with the new dispensation, also come new ethical challenges (Vorster, 2007:vii). Ethics give people guidance in their daily choices for the correct conduct in the midst of an imperfect society (Fourie, 1998:255). The attitude of Christ, given in Philipians 2:5-11, namely love, stewardship, self-denial and obedience to God, serves as a basis for Christian ethics and as guideline for all relationships and activities (Vorster, 2007:20). The areas which will be discussed where there are serious challenges to Christian ethics are technology, education, business and public morality.

\subsubsection{In the information technology field}

The 21st century is characterised by unprecedented advances in technology and developments in the cyber world, but Lotter (2006:34) rightly observes that consideration should be given to the potential damaging effects. Lategan (2003a:365) affirms that many policies are in place at higher education institutions for the application of technology in science and management, but little is done on the normative position with regard to the use of technology. Technology may not be allowed to be practised without any boundaries - an ethical framework is necessary. Lotter (2006:9) gives an example of the Pro-Ethics Pledge (http://www.iwanet.org/ documento.asp?.id=12) which tries to ensure web professionalism and ethics. Through the pledge, subscribers of the world wide web 
(www) commit themselves to "uphold principles of integrity" and to strive towards fairness and responsibility. Such an ethical framework can protect people against the harmful influences of the information technology.

Another possible detrimental effect of the information technology is the ever increasing threat to privacy on the www. Features of the www like traceability, registration of data, calling line identification and central control make the treat to the privacy of the individual using the www very real. The Private Coalition (coalition@privacy. org) is an example of a non-partisan coalition in favour of legislation to effectively ensure individual privacy (Lotter, 2007b:3, 8-10, 1314).

\subsubsection{In the education field}

The presence of violence, drug abuse and cellphone pornography causes a new concern for ethics in schools and higher education institutions. An attempt to instil ethics without religion and moral values, however, is in vain (Hollands, 2007:1; Lantos, 2001:2; Keating, 2007:5; Smith, 2007:4; Spies, 2007:1). Education is more than just transmission of knowledge - it is the raising of children to maturity, the forming of people with healthy values who are able to choose between right and wrong and the development of character. Values and ethics, grounded in the Bible, play an enormous part in this process (Lantos, 2001:15; Rens, 2005:59-60).

The practice of education has changed and will continue to change with the rapid development of new technology. Using the information technology in the field of education is imperative, but normative guidelines should be in place to regulate it (Strijbos, 2006:8). Not only should ethics determine the curriculum of higher education institutions which are underwriting the Christian ethos, e.g. abortion techniques (in the context of "abortion on demand") may not be taught in the training hospitals of such institutions, but it should also be included in the curricula of all scientific disciplines, as students are the employers and employees of the future who could influence the societies within which they will work (Lategan, 2003a:363, 365366). Such education can prepare students to be honest and responsible citizens and leaders (Kinoti, 1994:54).

\subsubsection{In the business field}

Corruption is a serious problem in the business society with Fidentia still fresh in the memory of many South Africans (Goredema, 2007: 
9). The World Democracy Audit of May 2007 states that South Africa is in the 41st place in the world's corruption rank (Anon., 2007c). The Global Economic Crime Survey 2005, undertook by PricewaterhouseCoopers, involved 3634 senior executives in 34 countries. Of these companies, $45 \%$ were victims of fraud and an alarming $83 \%$ of the South African companies indicated that they experienced fraud (Anon., 2005:1).

The ruins of Enron and WorldCom are testimonies of the destructive power of greed and dishonesty. Time magazine named the two "whistleblowers", Sherron Watkins (Enron) and Cynthia Cooper (WorldCom), as persons of the year. Cooper, when asked how she managed not to fall prey to the corruption in the company, responded that it was because of the values and ethics which she learned through her life, especially from her mother. Business ethics, based on transparency and accountability, assist people in their daily decisions to make the right choices, even if they are alone (Ramsay, 2003). A study in several American states showed that ethics-driven companies outperformed others (Lategan, 2003b:212). People with Christian values work and lead in a different way and can have a huge impact (Curran, 2000:65).

\subsubsection{In the public morality field}

As a result of the liberal constitution in South Africa, many laws that prescribed a conservative public morality have been liberalised. Many Christians experience a tension between the lifestyle and values they were taught at home and the lifestyle and values rampant in the world. Consequently, believers feel that their traditional Christian lifestyle and values are no longer applicable to a large portion of their lives. Christian ethics, however, can help them to develop an integrated, contemporary Christian lifestyle that will enable them to live authentic lives in society and influence public life effectively (De Villiers, 1999:87, 89). This corresponds with the opinion of Stanley Hauerwas who concludes that virtue and character provide a better framework for reflection on moral life than mere moral rules (cf. Porter, 2001:107).

Faith in Jesus Christ has spiritual, ethical and social implications for believers. They should be agents of Biblical, moral and ethical principles in this world (Turaki, 1997:147-148). The prophetic voice of the church may not be quiet in the face of political, social and economic evils. The church has the task to preach and teach morality, to insist on morality at every level and its members have to live exemplary lives (Kinoti, 1994:12; De Villiers, 2000:447-449). 


\section{The responsibility of Christians/churches in the world}

As indicated earlier, Christianity always implies the church and therefore a discussion of the responsibility of the individual Christian is also connected to the responsibility of the church. American churches are sometimes depicted as consisting of two types, the "private" church (primarily concerned with the saving of souls) and the "public" church (active in social structures to create a better society). The most influential propagator of the "public church" viewpoint was Reinhold Niebuhr (Hauerwas \& Willimon, 1989:31). He was against both the anti-culturalism of exclusive Christianity and the accomodationism of culture-Christians and believed that Jesus Christ can transform all things so that God can be glorified in all vocations (Niebuhr, 1952:197, 207, 217). Although this debate has been raging in the USA, the same issues apply in South Africa, as will be explained. Christians, indicate Van der Walt (2006:33-34) and De Villiers (2005:521) (both from a South African context), should contribute to society's transformation by means of a comprehensive view of full-time service to God, independent of the profession. Turaki (1999:22) and Kinoti (1994:11) declare that Christianity can only influence the world effectively if it continually addresses the economic, political, social, cultural and educational areas of life. Due to the limitation of an article, these areas will only be touched upon and not discussed in depth.

\subsection{Politics}

As a result of the political changes, many Christians have "emigrated inwardly", dissociated them from the public sphere and withdrew to personal relations, interests and religious experiences (De Villiers, 2005:523). Withdrawal is not an option, argues De Villiers (1999:83), because Christians should be involved in the building of a new, just and democratic society. Packer (1985:6-8) and Kinoti (1994:7-8, 82-83) state that Christians should not see politics as a "worldly" business and thus not fulfil their political responsibility. Firstly, Christians should be well informed about politics in order to vote and pray for government. Secondly, those with an interest and ability for a political career should pursue it. In this regard Theron (2007:8) reports on an interview with a Christian leader. Thirdly, Van der Walt (2003:296) calls attention to the important role of Christians to criticise government. An example of such criticism is the statement of 13 October 2006 by leaders of Christian churches in South Africa on crime and violence. They made it clear that the elected political leaders are responsible to eradicate crime and 
violence and that citizens have the right to expect the state to protect them against violent misdeeds (Anon., 2006a).

Although South Africa is a secularised state since 1994, government encourages faith based communities to play an active role in the formulation of public policy and help with moral regeneration (Duncan, 2002:334-335). On 30 January 2007, the then deputy president of South Africa again asked religious bodies to take part in the Moral Regeneration Movement (Mlambo-Ngcuka, 2007). When it comes to moral issues, according to Hartin (1997:30-33), the citizens of a democratic country have a responsibility to voice their views. The church has no choice but to be critically and constructively involved in the political arena. The Dutch Reformed Church did this with the press release at the end of the 2007 general synod meeting. In it they criticised the government inter alia for its hesitation to actively fight violence and crime, for protecting esteemed ANC figures who allegedly committed crimes and for not taking serious the importance of exemplary leadership and denouncing any hint of corruption in the government. The general synod committed itself again to be a prophetic voice whenever deemed necessary (Anon., 2007b).

\subsection{Society}

Since 1994, South Africa underwent extensive transformation processes and these left especially white South Africans feeling insecure. Some believe that they cannot contribute anything to change the situation and therefore withdrew from the problem areas in society, while others have played a considerable role in the new South African society (De Villiers, 1999:81; Duncan, 2002:334; Kingma \& Lotter, 2002:319; Steyn \& Lotter, 2006:541-542, 551). It is better, asserts Du Plooy (2004:8), to take note of the negative things in society and to be part of the solution. Van der Walt (1999:22-24) agrees that Christianity may never be confined to the private life, but must influence society by serving God in all areas of life. The church must maintain its prophetic calling to ensure positive change and its members must be empowered to be part of the transformation of society (Steenkamp, 1996:746; Duncan, 2002:340). Sir Frederick Catherwood, a Christian member of the European Parliament, said: "To try to improve society is not worldliness, but love. To wash one's hands of society is not love, but worldliness." (Cf. Packer, 1985:4.)

In order to play a role in the transformation of society, Christians are encouraged to develop an adequate, contemporary Christian social ethics and formulate a Christian vision of a good society. The development of Christian social ethics entails the recognition of the 
Lordship of Jesus Christ in all social spheres and the acceptance of Biblical moral values as the only measure for policy formation and action. This is highly problematic in a non-Christian society, therefore an ethics of responsibility is proposed where people must take responsibility for their decisions (De Villiers, 2005:521, 526-530). South Africa is following the worldwide phenomena of developing into a human rights culture. Duties and responsibilities always go hand in hand with rights (Lotter, 2007b:5).

\subsection{Economy/business}

Progress has been made over the last decade regarding nationbuilding in South Africa, but the soaring levels of corruption are intolerable (Vorster, 2007:39). News headlines often carry reports of large scale corruption in the public and private sectors (Gounden, 2007:2; Makapela, 2007:3). The values of the free market economy, like competition, consumption and the accumulation of material possessions have been taken over by Christians although they are hardly compatible with traditional Christian values (De Villiers, 1999:86). Some Christian ethicists even claim that the economic life is foreign to faith and that theology has no place in business ethics. Vorster (2007:130), on the contrary, believes that Christians can have a gigantic influence in the corporate world by being responsible stockholders and stakeholders and by setting the example that business is not only about making profit, but also about serving people.

There are several factors which caused a renewed interest in business ethics. Lategan (2003b:212) mentions globalisation, new business practices like electronic marketing and commerce, worldwide economic scandals and ideologies like consumerism. This new interest in business ethics is also detectable at many universities as they include it in the training of business managers. Vorster (2007: 130) urges business schools to mould the principles of business ethics into practical and realistic ethical guidelines for responsible corporations. There are four core values for corporate governance which should receive attention, namely fairness, accountability, responsibility and transparency. Value-driven organisations should consistently evaluate whether they "walk their talk" - whether their values are integrated in all their activities. Managers should demonstrate their moral integrity through responsible ethical decisions not to be guided by what is acceptable, but by what is right (Lategan, 2003a:361-362; Lategan, 2003b:221). 
Churches should provide their members in the business world with opportunities to discuss how they can integrate their Christian values in their businesses (Knapp, 2004:10, 12-13) and Silvoso (2006:22) argues for a fresh positive approach of Christians towards business and the marketplace. There are some Biblical principles, suggested by Gardner (1997:55-58), which Christians should apply in their business endeavours:

- Profit - the quest for profit may not cause unscriptural behaviour.

- Process - the manner of doing business should be a testimony, e.g. no exploitation or abuse of human and material resources.

- People - there should be mutual respect and dignity between employees and employers.

- Product - the quality of the product should be above reproach and not detrimental to consumers.

- Price - it should be fair.

Christianity can provide an integrated Christian worldview and a relevant Christian work-ethics to address problems in the business world (Ogeke, 1998:25; Vorster, 2002:487-488).

\subsection{Education}

The primary educators of values in children are the parents, but in the current broken society where parents are absent, children often have other role-models in society for the development of morals and other values, like peer groups, the media and especially television characters (Rens, 2005:64). Teachers can have a huge impact on students. They do not only influence through content, but also through contact (McFarland, 2007). Teaching is not only about the curriculum, but also about being open to students and to pray for them. Teachers should share with their students their vision and sense of vocation, what inspires them and what excites them. Instead of cursing the darkness, Christian teachers should light the candle, that is, not defining their position in terms of what they reject, but in terms of what they whole-heartedly stand for (Kok, 2004:106). Christian educators, as Rens (2005:70) indicates, should regard Biblical character-building as part of their duty and in doing so, equip their learners for life. In order to ensure that learners will, as adults, act ethically, Christian educators should not only provide intellectual education to their students, but also be committed to the religious 
regeneration of their students - the basis of character transformation and the work of the Holy Spirit (Lantos, 2001:16, 25-26).

\subsection{Science}

During modernity science presented itself as the means to solve all problems, but it also induced new problems, to the effect that society should prescribe limits for the application of scientific knowledge, e.g. in the area of bioethics (Voyé, 1999:277-278). These ethical issues should be handled by government, but in Belgium, France and the Netherlands, the governments often approach religious actors for advice. Although the contemporary world is secularised, it seems as if governments acknowledge that no other institution has developed competence in the ethical field like religion. Vorster (2002:493) agrees that when it comes to ethical issues regarding human life, the church has the responsibility to enter the debate. Strijbos (2006:7) refers to the Centre for Philosophy, Technology and Social Systems at the Vrije Universiteit of Amsterdam where one of its objectives is to carry out an interdisciplinary research programme into the management and design of technology and social systems with a high priority on ethical and other normative issues.

Although the relationship between science and religion has always been strained with scientists like Richard Dawkins and Steven Pinker who view religion as a relic of the pre-scientific past and believers on the other hand who see science as morally nihilistic, there are also people like Francis Collins who believe that science and religion can be reconciled. As leader of the Human Genome Project (aimed at healing innate human disorders), he is one of the world's most influential scientists and advocates that the God of the Bible is also the God of the genome and He can be worshiped in the cathedral and in the laboratory (Horgan, 2007:35). Collins believes that one can be a rigorous scientist, demanding evidence before accepting any conclusions, but also a believer whose life is influenced by his/her relationship with God. The field of human genetics offers the potential to alleviate human suffering, but also needs to be regulated to minimise inappropriate uses. Collins devotes $5 \%$ of this multibillion-dollar research program to ethical issues, involving a host of social scientists, ethicists and theologians (Tennant, 2001:42-43).

Sir John Templeton is a pioneer in the field of science and religion and started a foundation to encourage the dialogue between these two disciplines in the belief that religion and science can supply mutual illumination and appreciation of the wonders of the universe 
and motivate people to investigate and comprehend the truth in a new way (Barrow, 2006:19; Giberson, 2006:5). The Templeton Foundation started and funds the Science \& theology news which gives concise reviews on activities in the field and reports on topics like the big-bang theory, the world baby-making market, evolution, intelligent design, cloning, in vitro fertilisation and cosmological breakthroughs. The Harvard Divinity School joined the ranks of the Oxford University, Princeton Theological Seminary and other major universities in the world in exploring the religion-science relationship in a prestigious way (Ferguson, 2006:14).

\subsection{Media}

It is the task of the public media to serve the interest of society and to report on prejudicial issues (Fourie, 1998:266). After 1994, Christians in South Africa lost their privileged position of access to the media (De Villiers, 2005:523-524). A greater number of committed Christians need to join the profession in order to win it back and ensure that Christian principles determine the practice of the profession (Shorter \& Onyancha, 1997:84-85). Only then the purpose of communication, namely to give information, to educate and entertain people and to build understanding in human communities, will be fulfilled again. The content which is communicated should always be truthful, constructive to human values and advantageous for freedom and justice. The media can play a massive role in the changing of values and the fight against injustices (Balasuriya, 2001:33-34, 37-38).

Christians should use new media technology to impact the community, e.g. Christian radio and television broadcasts. Digital technology and the internet can be used for religious publications and interactive websites, especially for Christians in "closed" societies (Anon., 2006b:38-39).

Two examples are: www.echurch.co.za (spiritual material accessible to Christians worldwide) and www.kwamjing.net (an interactive Bible study programme for Thai Christians).

\subsection{Justice}

Believers should advance God's justice in the world by persistently reminding government of its responsibility to maintain order in society. The church also has the responsibility to be a mouthpiece for minority groups, for the oppressed, for children and women (Vorster, 2002:406, 493). Since 1994, the Christian faith has no longer pre- 
ference in the South African legislation and the administration of justice may sometimes be in direct conflict with Christian principles. If Christians do not agree with government, it is their task to use all possible communication channels to bring attention to it (Pienaar, 2006:18-19). Churches should encourage their members to use the constitutional road to expose and address any form of injustice. If it is not successful and they continue to experience discrimination, they should demonstrate that Christ is their Lord by not becoming angry, by continually doing good (1 Pet. 4:19) and by continuing to be a witness about the hope (1 Pet. 3:15) that is living in them (Janse van Rensburg \& Pienaar, 2005:48-49).

The aim of the Truth and Reconciliation Commission was to bring reconciliation and healing to the South African society. Forrester (2001:205) and Storey (2007) comment on the fact that the TRC used a "different kind of justice" as they worked under the banner of "Healing through truth". The justice they followed had in mind to promote healing and restoration. The TRC hearings reached beyond the limitations of secular law in order to attain forgiveness and national reconciliation. In practice, they applied an almost Scriptural understanding of justice: remember, judge and forgive. Justice should rather seek restoration than retribution. One police officer, who masterminded an attack on a rural village, faced his victims and said: "I can never undo what I have done, and I have no right to ask your forgiveness, but I ask that you will allow me to spend my life helping you to rebuild your village."

Dignity, equality and freedom are some of the values pursued in the South African Constitution. These values are also the core values of the Charter of Human Rights. The aim of human rights is to protect the individual against collective abuse of power and not, as many church leaders wrongly believe, an ethical concept enforcing secular morality on citizens (Vorster, 2002:115, 168, 174, 250). A common response of Christians to the concept of "human rights", according to Coetzee (1999:8), is that people have no rights, only privileges. This is true for the vertical relationship between man and God, but not for horizontal relationships. Between people, privileges become rights which should be mutually acknowledged and respected. The rights of one person become the responsibility of others towards that person. Vorster (2002:484) agrees that human rights are not possible if there is no moral responsibility. 


\section{Proposed guidelines for Christians on influencing the unbelieving world}

- Christians should be aware of their worldview, as it serves as a compass to orient them in the world.

- Parents are primarily responsible for the transmission of values and the internalisation of values is more successful if children experience their parents' religion as credible and not mere lipservice.

- The attitude of Christ, namely love, stewardship, self-denial and obedience to God, should serve as guideline for all relationships and activities in all areas of life.

- To be truly influential, Christians should live integrated, authentic and contemporary lifestyles.

- Christians should be agents of Biblical, moral and ethical principles in this world by not keeping quiet about political, social and economic evils.

- Christians should influence the corporate world by being responsible stockholders and stakeholders (business is not only about making profit, but also about serving people).

- Christian educators should not only focus on the curriculum, but also equip learners for life through Biblical character-building.

- Christians in the communications media should ensure that the communicated content is truthful, constructive to human values and advantageous for freedom and justice.

- Christians should impact the community through Christian radio and television broadcasts. Digital technology and the internet should be used for alternative evangelism purposes.

- Believers should have a valid Scriptural understanding of justice, namely to promote healing, restoration, forgiveness and reconciliation. Justice should be restorative and not retributive.

\section{Conclusions}

In this article it was argued that Christians should follow the example of Jesus Christ to be in the world (they may not isolate them from the world), but not of it (they may not accommodate the world). The integral Christian worldview guides and directs believers to "survive" the challenges of the 21st postmodern century and to positively 
influence the unbelieving world around them because it impacts the whole life of the believer, to obey and honour God in every aspect of life. It enables believers to relate their faith to all areas of life by motivating them to live out their calling and responsibility to make the world a better place. Christians have no choice but to be critically and constructively involved in the political, economic, social, judicial, scientific and educational areas of life. The world needs a holistic Christianity which emphasises full-time service to God, independent of one's profession.

\section{List of references}

ALFEYEV, H. 2005. European Christianity and the challenges of militant secularism. The ecumenical review, 57(1):82-91.

ANDERSON, N.T., ZUEHLKE, T.E. \& ZUEHLKE, J.S. 2000. Christ centered therapy. Grand Rapids: Zondervan.

ANON. 2005. Media release embargoed: for release 29 November 2005. http://www.pwc.com/gx/eng/cfr/gecs/PWC_GECS05_South_Africa_PR.pdf Date of access: 16 Jul. 2007.

ANON. 2006a. Declaration by church leaders on violence and crime in South Africa. http://www.kerkweb.org.za/persverklaring. asp?pid=31\&sinid=22 Date of access: 13 Jul. 2007.

ANON. 2006b. Media in motion. Christianity today, 50(10):38-39.

ANON. 2007a. Towards a Christian worldview. http://thebigpicture.homestead. com/TowardsaChristianWrldview ns4.html Date of access: 16 Jul. 2007.

ANON. 2007b. Verklaring: landsituasie. http://www.kerkweb.org.za/pers verklaring. asp?pid=39\&sinid=22 Datum van gebruik: 13 Jul. 2007.

ANON. 2007c. The world democracy audit. http://www.worldaudit.org/ democracy.htm Date of access: 16 Jul. 2007.

ARCH, C.C. 2007. A critical response to: building a Christian worldview. http://goodnewsiowacity.com/new_page_11.htm Date of access: 16 Jul. 2007.

BALASURIYA, T. 2001. Communication ethics with a pluralist worldview. (In Lee, P., ed. Communication, reconciliation: challenges facing the 21st century. Geneva: WCC. p. 32-45.)

BARNA, G. 2006. Revolution. Vereeniging: Christelike Uitgewersmaatskappy.

BARNETT, P. 1999. The message of 2 Corinthians. Leicester: InterVarsity.

BARROW, J.D. 2006. The great basilica of nature. Science \& theology news, 6(8):16-19.

BERRY, R.J., ed. 2000. The care of creation: focusing concern and action. Downers Grove: InterVarsity.

BOSMAN, J. 2002. Pastoraat aan die Afrika-mens. Potchefstroom: PU vir $\mathrm{CHO}$. (M.Th.-verhandeling.)

BROWNING, D.S. 2006. Christian ethics and the moral psychologies. Grand Rapids: Eerdmans.

COETZEE, J.C. 1999. Menseregte: wat sê die Bybel? Die Kerkblad, 102(3058):8-10.

CURRAN, P. 2000. All the hours God sends? Leicester: InterVarsity. 
DE VILLIERS, D.E. 1999. Challenges to Christian ethics in the present South African society. Scriptura, 69(1):75-91.

DE VILLIERS, D.E. 2000. Die morele genesing van die Suid-Afrikaanse samelewing: die bydrae van die Afrikaanse kerke. Hervormde teologiese studies, 56(2 \& 3):440-455.

DE VILLIERS, D.E. 2005. The vocation of reformed ethicist in the present South African society. Scriptura, 89:521-535.

DU PLOOY, H. 2004. Die hede en 'n hoopvolle toekoms? Woord en daad, 387: 6-8.

DUNCAN, G.A. 2002. A place in the sun? The role of the church in moral renewal and social transformation. Verbum et ecclesia, 23(2):333-342.

ECHLIN, E.P. 2004. The cosmic circle: Jesus and ecology. Dublin: Columba.

FERGUSON, K. 2006. Harvard creates science-religion chair. Science \& theology news, 6(7):14.

FORRESTER, D.B. 2001. Social justice and welfare. (In Gill, R., ed. The Cambridge companion to Christian ethics. Cambridge: Cambridge University Press. p. 195-207.)

FOURIE, D. 1998. Toepassing van moraliteit in die Suid-Afrikaanse staatsdiens. Koers, 63(3):251-267.

FRENCH, W. 2005. Ecology. (In Schweiker, W., ed. The Blackwell companion to religious ethics. Malden: Blackwell. p. 469-476.)

GARDNER, B. 1997. Business ethics: a Christian perspective. The South African Baptist journal of theology, 6:54-58.

GARLAND, D.E. 1999. The new American commentary: 2 Corinthians. Vol. 29. Nashville: Broadman \& Holman.

GIBERSON, K. 2006. Deep reflection. Science \& theology news, 6(11 \& 12):5.

GOREDEMA, C. 2007. Fidentia case proves that fraud mechanisms are not working. Daily dispatch: 9, 15 Mar.

GOUNDEN, F. 2007. Metro policemen fired in corruption probe. Independent on Saturday: 2, 21 Apr.

HARTIN, P.J. 1997. Christian ethics in a pluralistic society: towards a theology of compromise. Religion \& theology, 4(1):21-34.

HAUERWAS, S. \& WILLIMON, W.H. 1989. Resident aliens: a provocative Christian assessment of culture and ministry for people who know that something is wrong. Nashville: Abingdon.

HEYNS, M. 2006. Die "antitese" - medisyne vir ons tyd? Woord en daad, 397:14.

HOEK, J. 2009. Calvijn en de gemeenteopbouw. (In De Greef, W. \& Van Campen, M., eds. Calvijn na 500 jaar: een lees en gespreksboek. Zoetermeer: Boekencentrum. p. 177-193.)

HOLLANDS, B. 2007. Sordid sex scare on cellphone chat system. Weekend post: 1, 3 Mar.

HOLLINGER, D.P. 2004. Worldview: the history of a concept. Christian century, 121(2):40-41.

HORGAN, J. 2007. Francis Collins: the scientist as believer. National geographic, 211(2):35-39.

HOWELL, B.M. 2006. Globalization, ethnicity, and cultural authenticity: implications for theological education. Christian scholar's review, 25(3):303-321.

HULST, J.B. 2004. Christian world view and scholarship. (In Hulst, J.B., ed. Christian world view and scholarship. Melbourne: Amani. p. 6-21.) 
JANSE VAN RENSBURG, J. 2000. The paradigm shift: an introduction to postmodern thought and its implications for theology. Pretoria: Van Schaik.

JANSE VAN RENSBURG, J.J. \& PIENAAR, G.J. 2005. Vreemdeling in jou eie land? Teologiese riglyne vanuit 1 Petrus, met 'n juridiese begronding. In die Skriflig, 39(1):27-52.

JORDAAN, T. 2000. Die nuwe etiek van doen. Insig, 146:30.

KEATING, C. 2007. Dugmore to clamp down on school violence. Cape Argus: 5,7 Jun.

KINGMA, B.R. \& LOTTER, G.A. 2002. Begrip vir die lewenskonteks van mense as 'n vereiste vir pastorale begeleiding. Koers, 67(3):309-328.

KINOTI, G. 1994. Hope for Africa and what the Christian can do. Nairobi: Aisred.

KNAPP, J.C. 2004. Bridging Christian ethics and economic life: how theological education falls short. http://www.southernunstitute.org/Bridging/Christian/ Ethics/Economic/Life.pdf Date of access: 26 Jan. 2006.

KOK, J.H. 2004. Learning to teach from within a Christian perspective. (In Hulst, J.B., ed. Christian worldview and scholarship. Melbourne: Amani. p. 99108.)

LANTOS, G.P. 2001. How Christian character education can help overcome the failure of secular ethics education. http://www.faculty.stonehill.edu/glantos/ Lantos1/PDF_Folder/Pub_arts_pdf/Why\%20Ethics\%20Education\%20Is\% 20Failing.pdf Date of access: 26 Jan. 2006.

LARNEY, T. \& LOTTER, G.A. 2006. The parental role in establishing Christian values as the starting point of kingdom citizenship in an African (South African) context. Unpublished paper delivered at the IAPCHE Conference in Nicaraqua, 14-19 November.

LATEGAN, L.O.K. 2003a. The free-wheeling society: what values should be on the agenda and the role of the Christian education in the promotion of these values. Nederduitse Gerefomeerde teologiese tydskrif, 44(3 \& 4):361-367.

LATEGAN, L.O.K. 2003b. What is business ethics? Tydskrif vir Christelike wetenskap, 39(1 \& 2):211-223.

LOTTER, G.A. 2004. Die huwelik en die reformasie. Die Kerkblad, 107(3168):26-27.

LOTTER, G.A. 2006. Dehumanization by cyberfication. Paper delivered at the IPSI Conference in Spain, February 2006.

LOTTER, G.A. 2007a. The influence on learner discipline of values transmitted by parents. Unpublished paper delivered at the International Conference on Learner Discipline at the NWU, 2-4 April.

LOTTER, G.A. 2007b. Ever-increasing threats to privacy on the www. Unpublished paper delivered at the 9th Annual Conference on wwwApplications, 5-7 September.

MAKAPELA, L. 2007. Corrupt SARS auditor given leave to appeal. Daily Dispatch: 3, 30 May.

McDOUGALL, D.G. 1999. Unequally yoked - a re-examination of 2 Corinthians 6:11-7:4. The master's seminary journal, 10(1):113-137.

McFARLAND, A. 2007. A teacher's influence: what should Christian parents do since American schools do not uphold a Biblical worldview? http://www.focusonthefamily.com/focusmadazine/parentfamily/A00000006 1.cfm Date of access: 16 Jul. 2007. 
MLAMBO-NGCUKA, P. 2007. Address delivered at the SANDF Moral Regeneration Movement Conference. http://www.thepresidency.gov.za/ main. asp?include=deputy/sp/2007/sp01301458.htm Date of access: 16 Jul. 2007.

NIEBUHR, H.R. 1952. Christ and culture. London: Faber \& Faber.

NOEBEL, D.A. 1991. Understanding the times. Manitou Springs: Summit.

NOORDEGRAAF, A. 2009. Calvijn en de maatschappelijke vragen. (In De Greef, W. \& Van Campen, M., eds. Calvijn na 500 jaar: een lees en gespreksboek. Zoetermeer: Boekencentrum. p. 259-277.)

OGEKE, F.J. 1998. 'n Christelike werksetiek in Afrika. Die Kerkblad, 101(3043):22-25.

PACKER, J.I. 1985. How to recognize a Christian citizen. Christianity today, 29(7):4-8.

PHILLIP, R. 2007. The deepening moral crisis in South Africa. Natal Anglican news, 17(1):1.

PIENAAR, G.J. 2006. Ons geloof en die Suid-Afrikaanse regstaat. Die Kerkblad, 109(3189):18-19.

PORTER, J. 2001. Virtue ethics. (In Gill, R., ed. The Cambridge companion to Christian ethics. Cambridge: Cambridge University Press. p. 96-109.)

PRIMAVESI, A. 2006. Ecology. (In Sawyer, J.F.A., ed. The Blackwell companion to the Bible and culture. Malden: Blackwell. p. 432-446.)

PRINS, J.M.G. 2001. Intensionele morele vorming: noodsaaklik in kerklike jeugbediening. Practical theology in S.A., 16(1):105-119.

RAMSAY, P. 2003. Large and small concerns: some thoughts on business and ethics. http://www.stjohnsinthecity.org.nz/about/document/StJMessenger March 2003.doc Date of access: 26 Jan. 2006.

RENS, J.A. 2005. Riglyne vir waarde-opvoeding in Suid-Afrikaanse skole. Potchefstroom: Noordwes-Universiteit. (Ph.D.-tesis.)

SCHOEMAN, P.G. 2004. Thoughts as to the location of ideology within the sphere of "belief systems". Tydskrif vir Christelike wetenskap, 40(3 \& 4):171-197.

SHAW, W.H. 2005. Business ethics. 5th ed. Belmont: Wadsworth.

SHORTER, A. \& ONYANCHA, E. 1997. Secularism in Africa: a case study. Nairobi: Paulines.

SILVOSO, E. 2006. Anointed for business: how to use your influence in the marketplace to change the world. Ventura: Regal.

SIRE, J.W. 1997. The universe next door: a basic worldview catalog. 3rd ed. Downers Grove: InterVarsity.

SMIT, D. 2002. "Christ transforming culture"? Nagedink oor die aard van die gereformeerde geloof. Acta theologica: essentialia et hodierna, Supplementum, 3:125-149.

SMITH, C. 2007. Meisie vrees skool na knipmes in rug. Burger: 4, 14 Jun.

SPIES, D. 2007. Drug abuse soars at high schools in bay. Herald: 1, 23 Feb.

STEENKAMP, L.J.S. 1996. Kerk en kultuur in 'n postmoderne samelewing. Hervormde teologiese studies, 52(4):746-764.

STEYN, R.S. 2005. Die impak van die postmodernisme op voorhuwelikse verhoudings: 'n pastorale studie. Potchefstroom: Noordwes-Universiteit. (Ph.D.-tesis.)

STEYN, R.S. \& LOTTER, G.A. 2006. Veranderende tendense en die implikasie vir jongmens-verhoudinge. Koers, 71(2, 3, 4):535-555. 
STOREY, P. 2007. A different kind of justice: truth and reconciliation in South Africa. http://gbgm-umc.org/NWO/99ja/different.html Date of access: 16 Jul. 2007.

STRIJBOS, S. 2006. Bezinning op wetenschap techniek en maatschappij: een nieuwere ontwikkeling in Nederland. Woord \& daad, 397:5-8.

TATE, A. 2006. Postmodernism. (In Sawyer, J.F.A., ed. The Blackwell companion to the Bible and culture. Malden: Blackwell. p. 515-533.)

TENNANT, A. 2001. The genome doctor. Christianity today, 45(12):42-46.

THERON, P.M. 2004. Pastoral guidance of the "unequally yoked" marriage partners. Potchefstroom: North-West University. (M.A. dissertation.)

THERON, P.M. 2007. Equipping Christians living in an "unequally yoked" context: a practical theological study. Potchefstroom: North-West University. (Ph.D. thesis.)

THERON, P.M. \& LOTTER, G.A. 2008. "Do not be yoked together with unbelievers": New Testament perspectives on how Christians should live and act in a society of diverging convictions. In die Skriflig, 42(2):281-304.

TURAKI, Y. 1997. Tribal gods of Africa: ethnicity, racism, tribalism and the gospel of Christ. Jos: Crossroads Media Services.

TURAKI, Y. 1999. Christianity and African gods: a method in theology. Potchefstoom: Institute for Reformational Studies.

VAN DER WALT, B.J. 1994. The liberating message: a Christian worldview for Africa. Potchefstoom: Institute for Reformational Studies.

VAN DER WALT, B.J. 1999. Godsdiens en samelewing: Christelike betrokkenheid op die markplein. Potchefstoom: Instituut vir Reformatoriese Studie.

VAN DER WALT, B.J. 2003. Morality in Africa: yesterday and today: the reasons for the contemporary crisis. In die Skriflig, 37(1):51-71.

VAN DER WALT, B.J. 2006. When African and Western cultures meet. Potchefstoom: Institute for Contemporary Christianity in Africa.

VAN DER WALT, B.J. 2007. Transforming power: challenging contemporary secular society. Potchefstoom: Institute for Contemporary Christianity in Africa.

VANGEMEREN, W.A. 1997. New international dictionary of Old Testament theology and exegesis. Vol. 2. Grand Rapids: Zondervan.

VANHOOZER, K.J. 1998. Mapping evangelical theology in a postmodern world. Evangelical review of theology, 22(1):5-27.

VERGEER, W. 1999. Die postmodernisme - 'n "gevaarlike reus"? Die Kerkblad, 101(3056):12-14.

VORSTER, J.M. 1999. Die ontwikkeling van postmoderniteit. Die Kerkblad, 101(3056):10-12.

VORSTER, J.M. 2007. Christian attitude in the South African liberal democracy. Potchefstroom: Potchefstroom Theological Publications.

VORSTER, N. 2002. Kerk en menseregte binne 'n regstaat: die profetiese roeping van die kerk ten opsigte van die vestiging van 'n etos van menseregte in Suid-Afrika. Potchefstroom: PU vir CHO. (Th.D.-tesis.)

VOYÉ, L. 1999. Secularization in a context of advanced modernity. Sociology of religion, 60(3):275-288.

WHITE, J.E. 2001. Evangelism in a postmodern world. (In Dockery, D.S., ed. The challenge of postmodernism. Grand Rapids: Baker. p.169-183.)

WOLTERS, A.M. 2005. Creation regained: Biblical basics for a reformational worldview. 2nd ed. Grand Rapids: Eerdmans. 
WRIGHT, C.J.H. 2004. Old Testament ethics for the people of God. Leicester: InterVarsity.

ZWEMSTRA, J. 2006. Sola Scriptura, sola gratia, sola fide. Die Kerkblad, 109(3192):20-21.

\section{Key concepts:}

Christians

unbelievers

Kernbegrippe:

Christene

ongelowiges 
